the fact that this palace was rebuilt after a fire in 1788 ; all date it as from the early I6th century. This volume contains all the details of the building, the contract with the master-builder, covering several folio pages; the agreement as to amount and cost of materials; the agreement to keep a certain sum deposited in the Monte della Pieta for the use of the contractor and his promise to forfeit the amount if the building is not finished on time. Artists, bricklayers, masons, cabinet makers, etc., all have their individual contracts.

In addition to the Barberini-Sciarra-Colonna documents, there are three small volumes belonging to Andrea di Luca Pitti, of the famous Florentine family who began the Pitti Palace and who were ruined by the Medici. These books, written in a crabbed, almost illegible hand, are full of interesting and valuable entries of money paid to city officials, to weavers, spinners, and for a variety of things of more or less importance. The entries are usually definite enough to be of positive value for the years they cover, $1568-1585$.

In one place we read:

"On this day I bought a pig at the Porta alla Croce net weight I 49 lbs. for I2I lire.

Tax at the gate . . . . . . . . . . . 2.13.14

Killing and salting. . . . . . . . . . . . . I

Quart of salt . . . . . . . . . . . 2

Quatrino of meal ... . . . . . . 2.4

Loss by bleeding . . . . . . . . . . . 73

Left to be salted and eaten about 70 pounds."

There are also records of daily expenses, for the table, money paid for exemption from offices, taxes, etc. Transcribed or even translated with proper annotations, these volumes would throw light on many aspects of Italian commercial history under the Grand Dukes. No one interested in the social and commercial history of Italy, of commerce and of banking, can fail to see how valuable this collection of documents is, how fortunate The Business Historical Society is to have so unusual a collection, and how equally fortunate the Graduate School of Business Administration is to have the collection in its custody, freely accessible to those who are able to use the information it contains.

\title{
China and the Foreign Devils
}

ThE name "Russell and Company," heading a package of business papers and correspondence, which lay for years a prey to white ants before they found their way to the Society, recalls perhaps the most romantic and one of the most remunerative of the trades carried on 


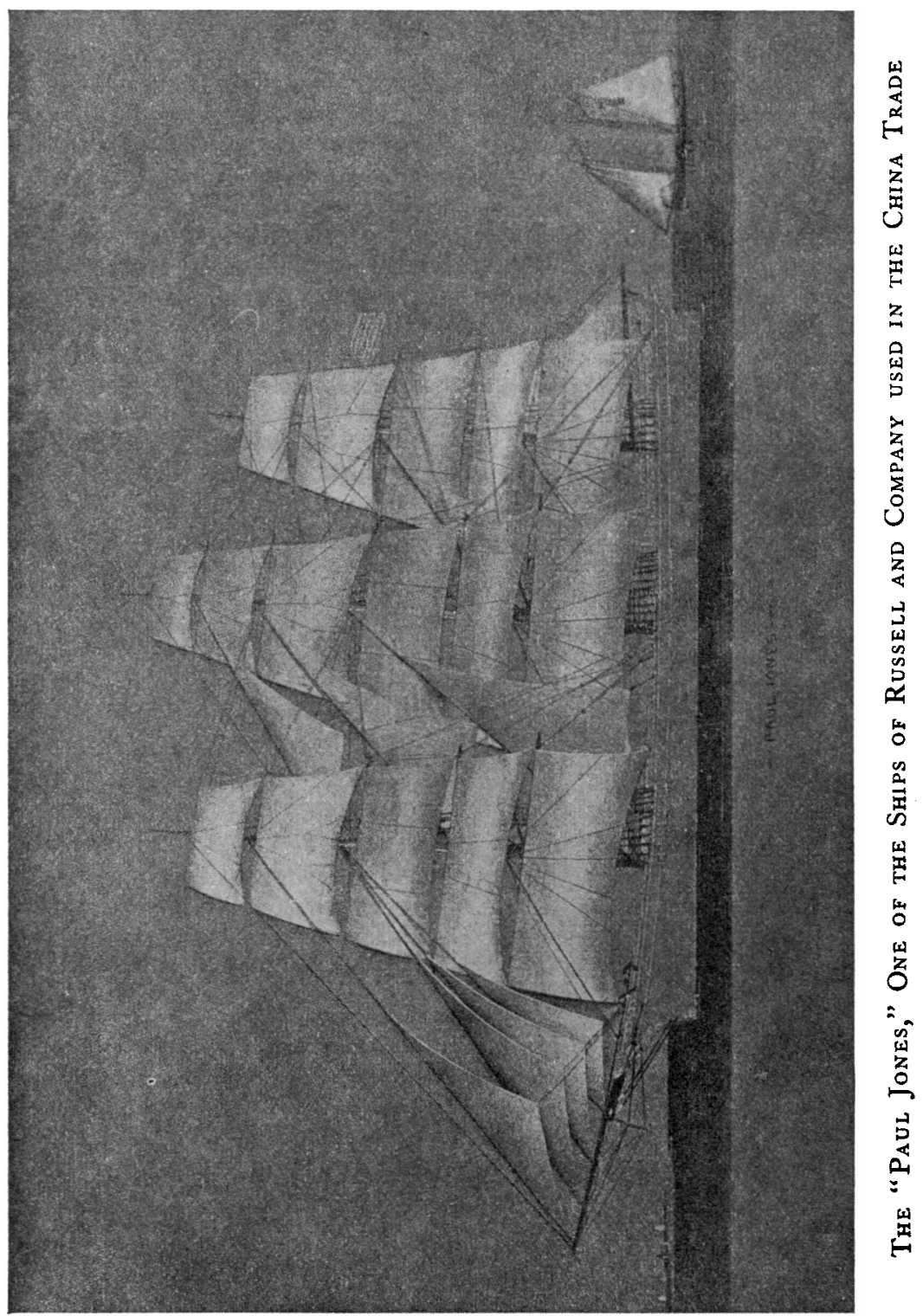


by American sailing vessels. Russell and Company was the bestknown American house at Canton in the pre-treaty period, when a few foreign merchants carried on a business there which ran up into the millions, in teas, silks, furs, sandalwood, opium, and western manufactured goods. A consolidation of several of the principal American firms, the company was for years the principal representative of the American business in Canton. The papers were a gift from Mr. Robert Shewan, of Shewan Tomes and Company, of Hong Kong.

Until the treaty of I 842 , when four additional ports were opened, Canton was the only city of the Celestial Empire to which foreigners were admitted. There alone the nineteenth-century West touched the borders of a past age, of a people leisured, still savoring of the days when the Old Testament was history in the making, and seasoned from ancient times in commerce. Alexander Michie, writing the biography of the second British minister to China, says, in describing the Chinese merchants:

"Of all the accomplishments the Chinese nation has acquired during the long milleniums of its history, there is none in which it has attained to such perfect mastery as in the science of buying and selling. The Chinese possess the Jews' passion for exchange. All classes, from the peasant to the prince, think in money, and the instinct of appraisement supplies to them the place of a ready reckoner, continuously converting objects and opportunities into cash. Thus surveying mankind and all its achievements with the eye of an auctioneer, invisible note-book in hand, external impressions translate themselves automatically into the language of the market-place, so that it comes as natural to the Chinaman as to the modern American ... to reduce all forms of appreciation to the common measure of the dollar."

It was this trait that led the Chinese to allow the despised foreigner even a precarious foothold within his gates. The outsiders, officially known as "barbarians" and "foreign devils," were segregated and regulated in a community by themselves. Thirteen hongs, long buildings several stories high and usually provided with broad verandahs, contained the counting rooms, go-downs (storehouses), offices, and living quarters of the merchants, each of the twelve principal nations represented occupying a building, and the thirteenth being known as the Chow-chow, or mixed hong.

Samuel Eliot Morison, in his Maritime History of Massachusetts, gives a colorful description of the approach to the foreign settlement 
as the Yankee trader, coming from the haunts of the sea-otter on the Northwest coast, by way of the Hawaiian Islands, passed between Luzon and Formosa, made Lintin Island, and, after running the gauntlet of piratical junks and pausing at the old Portuguese factory of Macao, sailed up the river past the Bogue forts to Whampoa, the anchorage for all foreign merchantmen:

"There the Hoppo came aboard to receive gifts for wife, mother, and self, and measure the ship for her 'cumshaw' duty. Thence her cargo was lightered in chop-boats twelve miles upstream to Canton, landed at Jackass Point, and stored in a factory or hong hired from one of the twelve Chinese security merchants, who had a monopoly of foreign trade, and acted as commercial godfathers to the FanKwae, or foreign devils.

"To the Yankee seaman, fresh from the savage wilderness of the Northwest, how marvelous, bewildering was old Canton! Against a background of terraced hongs with their great go-downs or warehouses, which screened the forbidden City of Rams from foreign gaze, flowed the river, bearing a city of boats the like of which he had never dreamed. Moored to the shore were flower-boats, their upper works cunningly carved into the shape of flowers and birds, and strange sounds issuing from their painted windows. Mandarin boats decorated with gay silk pennants, and propelled by double banks of oars, moved up and down in stately cadence. Great tea-deckers, with brightly lacquered topsides and square sail of brown matting, brought the Souchong, Young Hyson, and Bohea from up-river. In and out darted thousands of little sampans, housing entire families who plied their humble trades afloat. Provision dealers cried their wares from boats heaped high with colorful and deadly produce. Barbers' skiffs announced their coming by the twanging of tweezers, emblem of their skippers' painful profession. Twilight brought the boat people to their moorings, a bamboo pole thrust in oozy bottom, and paper lanterns diffused a soft light over the river. For color and exotic flavor there was no trade like the old China trade, no port like Canton."

The twelve merchants referred to together formed the Co-hong. Each foreign trader was secured by one of these merchants, as were also the compradors, or general factotums attached to the various establishments. A factory meant the offices and quarters of a particular firm. The personnel consisted of the tai-pan, chief of the house, and other partners, the "pursers" (clerks or assistants), the compradore, the linguists, the shroff, or money dealer, and the coolies. 


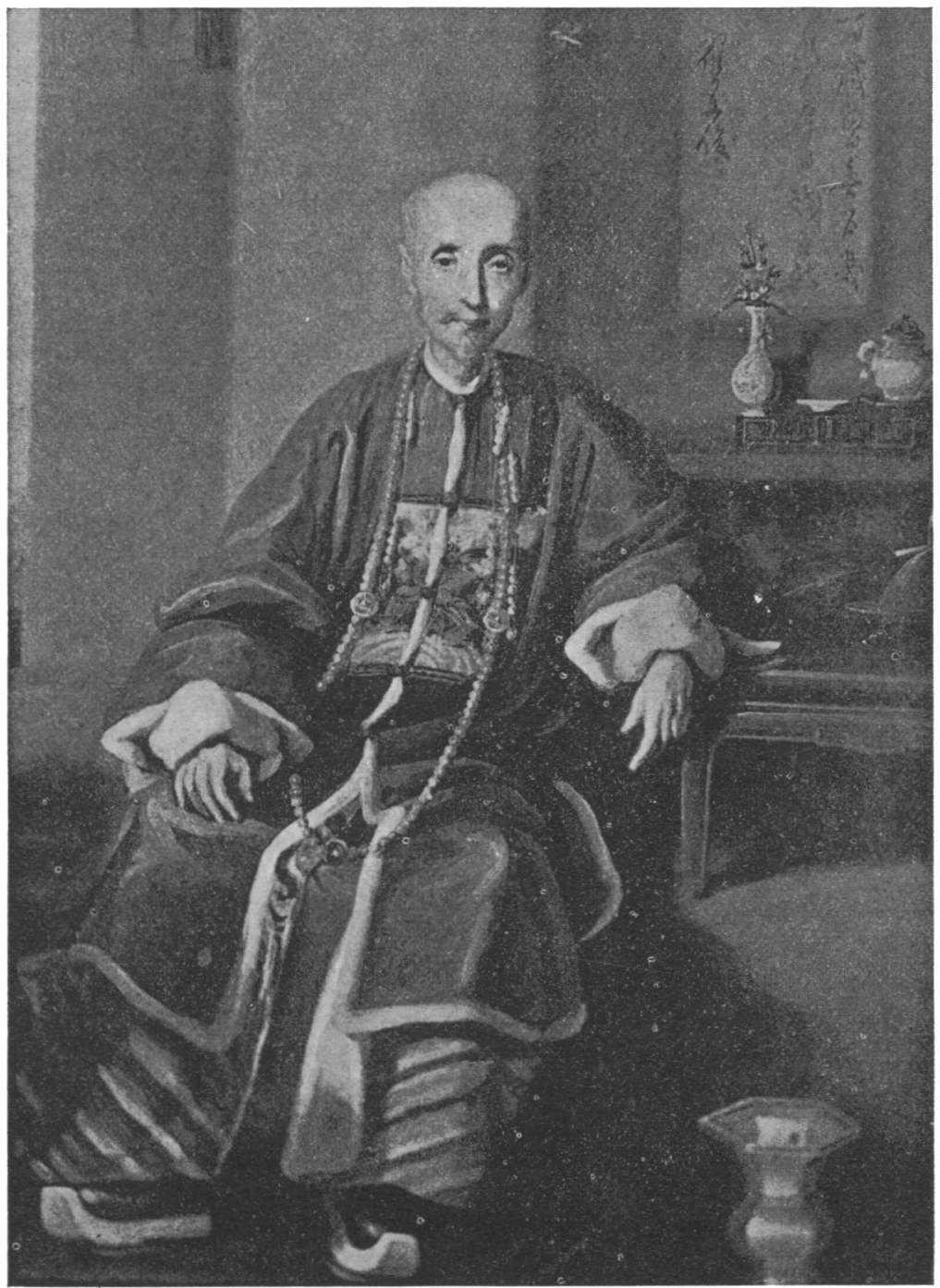

Houqua, the Senior Hong Merchant at Canton in Pre-Treaty Days. The Hong Merchants acted as Commercial Godfathers to the "Foreign Devils" 
An old resident of the factories and partner of Russell and Company, William Hunter, characterizes the linguists as being so called because they knew no language but their own. They were Chinese, versed in Pidgin-English, who were appointed by the Hoppo, or customs official, to act as interpreters for the foreigners. The principal linguists were know as Old Tom, Young Tom, and Alantsae. One of the eight principal regulations which were supposed to govern the behavior of the foreign devils provided that a linguist must accompany foreigners "taking the air" on a visit to the Flower Gardens or the Honam Joss-house. These excursions were permitted on the 8 th, 18 th, and 28 th days of the moon, but even then they had to be made in "droves of not over ten at a time."

Another regulation stipulated that "neither women, guns, spears, nor arms of any kind can be brought to the Factories."

The former rule, like a number of others, notably that against smuggling in opium, officially designated as "foreign mud," was more honored in the breach than the observance. Opium was regularly carried from the rendezvous at Lintin Island to its various destinations by swift boats known as "scrambling dragons" and "fast crabs," under the sanction of the official wink. The order against bringing women to the factories was, however, kept for the most part, and a bachelor community life reigned at the hongs.

There were compensations for the semi-exile in which the China merchants lived for years at a time, in the factories during the tea season, and at the cooler Portuguese settlement at Macao, directly on the sea, in the summer.

"The Factory," says Hunter, referring to the East India Company, "entertained with unbounded hospitality and in a princely style. Their dining-room was of vast dimensions, opening upon the terrace overlooking the river. On the left was a library, amply stocked; on the right a billiard room. At one extremity of the dining-room was a life-size portrait of George IV in royal robes, with crown and sceptre. ...

"From the ceiling depended a row of huge chandeliers with wax lights; the table bore candelabra, reflecting a choice service amidst quantities of silver plate."

At the date of the papers, however, all this had passed. The old order, with the entente cordiale which existed between Co-hong and foreign merchants, the well-understood, liberal interpretation of customs laws and regulations, the varying degrees of severity in whose wording simply meant a more or less urgent demand for money on 
the part of the officials, was swept away in the years between 1839 and 1842 , by the Opium War. A sudden right-about-face on the part of the government in its policy in regard to the smuggling of opium, from the playing of an elaborate game of words which meant one thing and said another, to a sincere intention to stop the importation of the drug, was the match that lit the train of powder. The real issue lay between the restless progressiveness of the West and the eternal conservatism of China. Sooner or later occidental trade was bound to break down the barriers which held it back from a new field so rich in possibilities.

By the decade of the 'sixties, a number of ports and the Yangtze River were opened to foreigners for trade, and foreign legations had been established at Peking, a privilege only wrested from the Chinese at the point of the sword. The old thirteen factories were burned, the British colony of Hong Kong had been established on a rocky and desolate island and had grown to the proportions of a flourishing city, and the center of trade had shifted from Canton to Shanghai.

In their references to routine transactions, the Russell and Company letters from the Hong Kong house to what was now the Canton branch show the changes that two and a half decades had wrought. After the extinction of the Northwest fur trade, the imports by American firms had long been drawn first from British, and then from New England manufactures. Sandalwood was another article imported in the early days in exchange for silks and teas. The story goes that a captain, sailing from New York for John Jacob Astor, stopping at the Sandwich Islands for a fresh supply of provisions, took the opportunity to restock with firewood. When he arrived at Canton, a mandarin who was among the visitors to the ship noticed the firewood, and asked the price of it. The captain was amused at the question, but said he was open to an offer. The mandarin offered five hundred dollars a ton. The fuel the captain had taken on at the Sandwich Islands was sandalwood. For seventeen years the secret was kept, and John Jacob Astor enjoyed a monopoly of the article. After that sandalwood took an important place among Canton imports. In the letters we see the decadence of this once profitable trade. A postscript to one of them says:

"We are not disposed to sell any sandalwood at present rates The trade at the South Sea Islands seems to be on its last legs, and we don't look for any further receipts of wood from that quarter beyond perhaps a small quantity now waiting shipment in Sydney." 


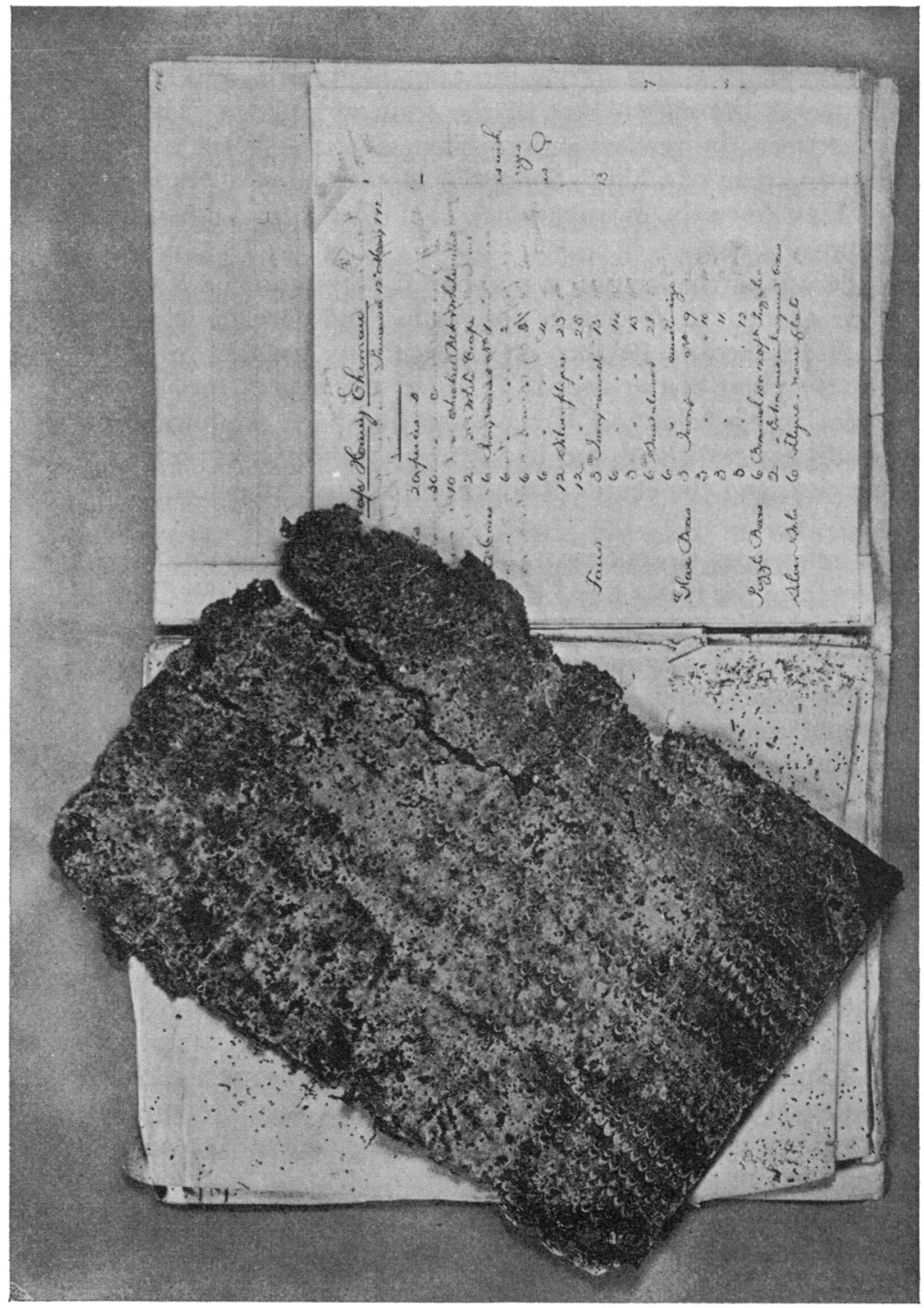

$Z$ w

究

家实

实

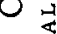

z⿺

党要

at

i 4

os

is

z

采

$\rightarrow 0$

0 A

(4)

35

䍃官

合:

z

要昰

出U

is

艺等

$4 \overrightarrow{0}=$

空

员

井

出 哇

जी

○ु

ค 出

崖

空

넝 농

山

资 
The character of exports had changed less. Teas and silks still appear as the principal articles mentioned, along with matting, white or red checked, for which there are many orders. There are a good many mentions of cochineal, vermilion, cassia, and tobacco. Quicksilver seems to have been a new article of import, to which there are a number of references. Rhubarb occurs once or twice, an article to which the Chinese attributed much importance in pre-treaty days, saying that the health of the western world was dependent on it.

Another letter gives us some idea of the South American market:

"This will introduce to you Mr. Julius Bernstein, who has come from Valparaiso to purchase a cargo for the Chilian market, and who will require more or less of a chow chow cargo from Canton.

"You will please furnish Mr. Bernstein with every information regarding matting, fire crackers, furniture, silk piece goods \&c to enable him to give us his orders when he returns to Hong Kong."

The early taste for Canton willow-ware had gone the way of the sea-otter and sandalwood, but in 1867 it reappears in a solitary order from a conservative gentleman, a member of one of the pioneer families in the Canton trade. Mr. Robert S. Sturgis wants a dinner set of the "usual blue Fitzhugh Chinaware," like several sent him between the years I86I and 1865 .

Directions that the set be insured at its face value, and another letter having reference to the Yangtze Insurance Association indicate an innovation in business methods. Insurance was a thing unheard of at Canton before the Opium War.

The ships mentioned in the letters are for the most part still sailing vessels, but here and there is a mention of the $\mathrm{P}$ and $\mathrm{O}$ steamers. Foreign craft, steamers in particular, were more and more supplanting the junks which had carried on the coastwise trade from time immemorial. Some sailing craft were used, decorated with an eye on each side like the native boats, in a characteristically Chinese gesture toward conforming to custom in name at least.

Robert Bennett Forbes, one of the most interesting and versatile of the merchants of his day, and head of Russell and Company for some years, was in the van of experimentation with steam for oceangoing vessels. He tells in his autobiography of sending two sailing vessels with auxiliary steam power to Canton as early as 1844 and '45. Both of them demonstrated their superiority to sailing craft to his satisfaction, but the Canton members of the firm had no confidence in them, and did not give them a fair chance. As late as 1867 the Hong Kong house writes to the Canton branch, in requesting the 
small steamer belonging to Mr. R. B. Forbes: "You can arrange with the Capt. of the 'Jeejebhoy' or 'Prince Albert' to tow her, much more cheaply, we think, than to let her steam down here."

There is a memorandum at the end of one letter directing the Canton house to "pay Houqua $\$ 35, \infty 00$, drawing upon us to provide funds." In I 867 the name Houqua still stood for honorable and upright dealing, as in the years before the treaty, when it was worn by the senior hong merchant. But a great change had come over the ethics of the Chinese mercantile community at large in its dealings with the foreigner. In the days of the old Canton factories, the word of either a Chinese or foreign merchant was as good as his bond. Promissory notes were almost unknown. The procedure was simply to "puttee book," that is, both parties recorded a financial transaction in their own books. The Chinese scorned the idea of litigation in connection with business obligations. A foreign merchant would have been perfectly safe in shipping a consignment of tea or silk received from any member of the Co-hong, without inspection.

The commercial honor of even the lesser Chinese business men is illustrated by a story in Robert Bennett Forbes' autobiography, of a second class silk dealer named Teeshing who had in his hands for dyeing several thousand pieces of crepe belonging to Mr. Cushing, the agent of Perkins and Company. A fire in the city had destroyed much property.

"After the fire was got under control the poor fellow came to $\mathrm{Mr}$. Cushing with a long face, lamenting his misfortunes. 'Well,' said Mr. Cushing, 'how-fashion speak and let me know the worst.' Teehsing answered, 'Ayah, my welly solly, my shop all gone; my pack-house all gone; my have lose eighty-five piece shawl.' It appeared he had turned his attention to saving the goods of his employer and was himself nearly ruined."

Chinese merchants were, as well, what they proudly called "largehearted." A favorite anecdote of Houqua is given by Morison in his Maritime History:

"Houqua's name was a household word in Boston merchants" families. They never tired of describing old Houqua tearing up the promissory note of a homesick Bostonian, with the remark, 'You and I olo flen; you belong honest man only no got chance. . . . Just now have setlee counter, alla finishee; you go, you please."

The letters reflect a sadly different level of honesty on the part of the Chinese. Complaint after complaint is recorded in regard to the quality of the silk. A considerable part of the weight of some was 


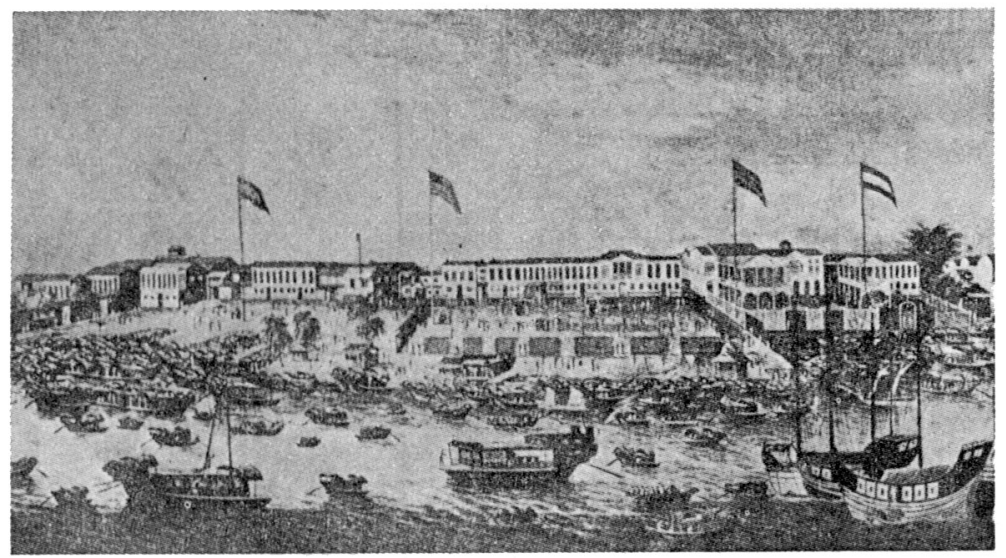

The Hongs of Old Canton

These buildings were the combined offices, storehouses, and residences of the foreign community at Canton in the early days of the China trade

due to the damp condition in which it was packed: The latest of these letters advises the Canton establishment to collect part of the value of the damaged silks from the various Chinese from whom they were bought.

"The matter needs thorough investigation," writes the correspondent from Hong Kong, "and we could advise that, in future shipments, the inspection be made by an experienced silk inspector, and not trusted to the honor of the Chinese dealers."

The forcible encroachment of the West on the carefully guarded seclusion of the ancient empire had substituted enmity and suspicion for the old friendly relations, precarious as they were, and without much real understanding on either side, and made it a virtue in the Chinese to thwart the intruder in every way. The battle was not yet won. The Chinese retreated step by step, still opposing a wall of passive resistance and elusive dealing to the onslaughts of the "barbarians."

\section{Backstage with Edison}

AN ITEM of timely interest has been discovered among a pile of old records given to the Baker Library by the United States Court of Appeals, in the facsimile of a notebook kept by Thomas A. Edison 